\title{
Tomasz Jarmużek, Marcin Tkaczyk, Normalne logiki pozycyjne, Wydawnictwo KUL, Lublin 2015, ss. 202.
}

\author{
W siedemdziesiąta rocznicę publikacji pierwszej pracy \\ o logice temporalnej
}

DOI: http://dx.doi.org/10.12775/RF.2016.032

W bieżącym roku przypada siedemdziesiąta rocznica opublikowania pracy Podstawy analizy metodologicznej kanonów Milla ${ }^{1}$ autorstwa polskiego logika Jerzego Marii Łosia. Jest to pierwsza na świecie praca z zakresu logiki temporalnej. Jej autor, Jerzy Łoś, choć urodzony we Lwowie, z powodu wojny kończył swoje studia w Lublinie, a następnie pracował w placówkach badawczych we Wrocławiu, Warszawie, a także w międzyczasie na uniwersytecie toruńskim. Jerzy Łoś był więc przedstawicielem trzeciego pokolenia słynnej Szkoły Lwowsko-Warszawskiej.

Nazwisko Jerzego Łosia jest znane $\mathrm{w}$ świecie $\mathrm{z}$ osiągnięć w logice matematycznej oraz algebrze, jednak jego pierwsze prace dotyczyły logiki filozoficznej, i w tej dziedzinie Łoś również miał istotny, choć niedoceniony dorobek. Recenzowana książka jest monografią będącą wyczerpującym opracowaniem i rozszerzeniem osiągnięć Łosia z zakresu logiki filozoficznej.

Wspomniany na wstępnie jubileusz wydać mógłby się błahym powodem - bowiem zarówno Łoś, jak i dzieło, które w pierwotnej wersji było jego pracą magisterska, pozostają mało znane w polskim, a co dopiero światowym środowisku filozoficznym. Ten stan rzeczy uznać można jednak za niewłaściwy, zważywszy na wagę dokonań Łosia w dziedzinie logiki filozoficznej. Poza wspomnianym artykułem, w którym opracowany został pierwszy w historii logiki system logiki temporalnej, Łoś w pracy Logiki wielowartościowe a formalizacja funkcji intensjonalnych ${ }^{2}$ sformułował pierwszy system logiki epistemicznej. Szczególnie zadziwiające jest to, że oprócz kilku zagranicznych, wczesnych i również pio-

1 J. Łoś, Podstawy analizy metodologicznej kanonów Milla, Annales Universitatis Mariae Curie-Skłodowska, 2.5. F, Lublin 1947, s. 269-301.

2 Idem, Logiki wielowartościowe a formalizacja funkcji intensjonalnych, Kwartalnik Filozoficzny, t. XVII, z. 1-2, Kraków 1948, s. 59-78. 
nierskich prac z zakresu logiki filozoficznej, prawie żadne późniejsze zagraniczne prace nie przyznają Łosiowi pierwszeństwa w logice temporalnej oraz epistemicznej, najczęściej zaś zupełnie przemilczają jego odkrycia. Jest to zwłaszcza uderzające w przypadku prac o charakterze historycznym, które z natury rzeczy powinny obejmować wszystkie pionierskie prace $z$ danej dziedziny. Recenzowana książka Jarmużka i Tkaczyka oddaje należny hołd polskiemu uczonemu poprzez popularyzację, kontynuację i rozwinięcia jego nowatorskich pomysłów.

Jak wskazują autorzy, logikę pozycyjną - której to właśnie twórcą był Łoś - uznać można za dziedzinę pośrednią między logiką modalną, a logiką hybrydową. Wszystkie te logiki umożliwiają relatywizację wartościowania zdań do punktów i traktują ich prawdziwość nie w sposób absolutny, jak czyni to logika klasyczna, lecz ograniczony względem pewnych wyróżnionych aspektów (stanów rzeczy, możliwych światów, momentów czasu, racjonalnych podmiotów itp.). W logice modalnej efekt ten osiąga się na poziomie metajęzyka, wskazując podzbiory wybranego uniwersum, w których prawdziwe są odpowiednie zdania atomowe. Punkty relatywizacji nie są jednak obecne w języku przedmiotowym. W logice hybrydowej czyni się inaczej, język rozszerza się o symbole, tzw. nominals, które traktuje się jako samodzielne zdania tworzące wraz ze zbiorem liter zdaniowych zbiór wyrażeń atomowych języka.

W logice pozycyjnej, podobnie jak w logice hybrydowej, punkty relatywizacji zwane również pozycjami wprowadza się na poziomie języka przedmiotowego. Nie traktuje się ich jednak jako samodzielnych wyrażeń, lecz jako termy (nazwy). Zgodnie z tym ujęciem, w języku naturalnym pozycje można interpretować jako wyrażenia typu "15 maja 2017 roku", natomiast symbole nominals jako "teraz jest 15 maja 2017 roku". Ponadto, w języku logiki pozycyjnej występuje specyficzny spójnik $R$ określany jako spójnik realizacji. Jest on funktorem zdaniotwórczym od argumentu nazwowego (denotującego pozycję) oraz zdaniowego, odpowiadającego quasi-wyrażeniu. Te ostatnie odpowiadają zdaniom, których wartość logiczna ustalana jest względem odpowiednich pozycji. Autorzy zawężają pole badań do normalnej logiki pozycyjnej gdzie normalność oznacza, że "logika klasyczna obowiazuje w ramach każdej pozycji oraz w opisie relacji między pozycjami"3 Minimalny system logiki pozycyjnej to system MR scharakteryzowany przez Jarmużka i Pietruszczaka ${ }^{4}$. Normalne logiki pozycyjnej należy więc uznać za wzmocnienia MR.

3 T. Jarmużek, M. Tkaczyk, Normalne logiki pozycyjne, Wydawnictwo KUL, Lublin 2015, s. 9.

4 T. Jarmużek, A. Pietruszczak, Completeness of Minimal Positional Calculus, Logic and Logical Philosophy, 13 (2004): 147-162. 
Przejdźmy do omówienia zawartości recenzowanej pracy. Książka Normalne logiki pozycyjne składa się z siedmiu rozdziałów i liczy 202 strony. Pierwszy rozdział o tytule Klasyczne podstawy zawiera prezentację pewnych pojęć z zakresu teorii mnogości oraz klasycznej logiki zdań i predykatów. Nie należy jednak tek części traktować jako wprowadzenia skierowanego do czytelnika nie mającego elementarnej wiedzy z logiki. Jest to raczej systematyczna prezentacja pojęć wykorzystywanych w późniejszych rozdziałach. Efektywna lektura wymaga zatem pewnego przygotowania.

W rozdziale drugim Geneza i rozwój logik pozycyjnych uwzględniona zostaje postać Jerzego Łosia jako twórcy tej logik pozycyjnych. W późniejszym czasie logiki pozycyjne rozwijane były również przez Nicholasa Reschera i Alsdaira Urquharta, którzy prace Łosia znali jedynie z anglojęzycznej recenzji napisanej przez Henryka Hiża ${ }^{5}$. Łoś wprowadził koncepcję logik pozycyjnych w swojej pracy magisterskiej napisanej pod kierunkiem Jerzego Słupeckiego i użył ich jako narzędzia do formalizacji rozumowań o charakterze temporalnym w naukach przyrodniczych. Zastosowanie operatora realizacji okazało się również owocne w dziedzinie logiki epistemicznej, co znajduje potwierdzenie w opublikowanym rok później artykule Łosia. Tym samym logika pozycyjna okazała się elastycznym narzędziem, w którym operator $\boldsymbol{R}$ daje się zinterpretować na wiele sposobów. Cecha ta została wyraźnie wyeksponowana przez autorów.

Kolejne rozdziały zawierają szczegółowe definicje i omówienie normalnych logik pozycyjnych, w których punktem wyjścia jest system MR. Rozdział trzeci nosi tytuł "Logika minimalnej realizacji MR" i zawiera obszerną prezentację systemu MR, która wykracza poza treść wspomnianego artykułu. Zaprezentowana zostaje aksjomatyka systemu oraz jej niezależność rozumiana $\mathrm{w}$ taki sposób, jak jest to zwykle robione w logice - poprzez podanie interpretacji wielowartościowej. Prezentuje się tam również modele systemu i dowodzi zgodności oraz pełności. Poza modelem zwykłym prezentuje się również model ogólny systemu. Modele zwykłe lepiej nadają się do badania rozszerzeń $\mathbf{M R}$, natomiast modele ogólne są znacznie bardziej użyteczne przy nienormalnych logikach pozycyjnych.

Kolejny rozdział "Alternatywne podejście do MR" wprowadza uproszczoną semantykę MR. Jest nią pewien podzbiór funkcji przypisujący formułom wartości logiczne, na które nakłada się odpowiednie warunki. Omawia się tam relację pomiędzy wymienionymi warunkami i poka-

5 H. Hiż, Reviews: Łoś Jerzy. Podstawy analizy metodologicznej kanonów Milla (Foundations of the methodological analysis of Mill's canons). Annales Universitatis Mariae Curie-Skłodowska, Sectio F, vol. 2 (for 1947, pub. 1948), pp. 269-301, Journal of Symbolic Logic, 16 (1951): 58-59. 
zuje niezależność aksjomatyzacji MR względem nowo zdefiniowanego modelu Zaprezentowany jest $\mathrm{w}$ tym rozdziale również nowy dowód zgodności, pełności oraz niezależność aksjomatyki.

Rozdział piąty zatytułowany "Bezkwantyfikatorowe rozszerzenia $M R^{\prime}$ zawiera alternatywne propozycje aksjomatyzacji systemu MR. Jedna z aksjomatyzacji pozwala na opis warunków normalności logiki pozycyjnej. Ponadto zaprezentowane są kierunki ewentualnych rozszerzeń systemu MR.

Rozdział szósty zawiera konserwatywne rozszerzenie MR do systemu MRQ, który zawiera logikę pierwszego rzędu. Na aksjomatykę MRQ składają się aksjomaty MR wraz z aksjomatyzacją klasycznej logiki kwantyfikatorów. Modelami MRQ są zwykłe modele MR. Udowodnione zostają tutaj również odpowiednie twierdzenia o zgodności i pełności.

W ostatnim rozdziale zaprezentowane zostają filozoficzne zastosowania logiki pozycyjnej. Omówione są dwie rekonstrukcje rozumowania Diodora Kronosa autorstwa Michaela oraz Reschera, które są sformalizowane właśnie dzięki zastosowaniu logiki pozycyjnej. Ponadto przedstawione są podstawowe informacje z zakresu normalnych logik modalnych, które następnie zostają zrekonstruowane w języku logik pozycyjnych.

W końcu należy również zaznaczyć, że omawiana monografia otrzymała w 2017 roku wyróżnienie Polskiego Towarzystwa Logiki i Filozofii Nauki. Ta nagroda świadczy o tym, że dokonania Łosia w zakresie logiki filozoficznej zaczynają mieć coraz większą recepcję i uznanie.

Krzysztof Aleksander Krawczyk

\section{Bibliografia}

Hiż H., Reviews: Łoś Jerzy. Podstawy analizy metodologicznej kanonów Milla (Foundations of the methodological analysis of Mill's canons). Annales Universitatis Mariae Curie-Skłodowska, Sectio F, vol. 2 (for 1947, pub. 1948), pp. 269-301, Journal of Symbolic Logic, 16 (1951): 58-59.

Łoś J., Podstawy analizy metodologicznej kanonów Milla, Annales Universitatis Mariae Curie-Skłodowska, 2.5. F, Lublin 1947, s. 269-301.

Idem, Logiki wielowartościowe a formalizacja funkcji intensjonalnych, Kwartalnik Filozoficzny, t. XVII, z. 1-2, Kraków 1948, s. 59-78.

Jarmużek T., A. Pietruszczak, Completeness of Minimal Positional Calculus, Logic and Logical Philosophy, 13 (2004): 147-162.

Jarmużek T., Tkaczyk M., Normalne logiki pozycyjne, Wydawnictwo KUL, Lublin 2015. 